\title{
Model of Primary School Teachers Training for Work in the System of Inclusive Education by Applying Extrapolation of Poland's Advances in Training for Work
}

\author{
Anna A. Sobchuk and Nataliia O. Mykytenko \\ Ivan Franko National University of Lviv, \\ Lviv, Ukraine
}

\begin{abstract}
The purpose of the study was to develop a model of vocational training of primary school teachers for work in the system of inclusive education by applying extrapolation of Poland's advances in training for work and to identify how it was evaluated by the experts in Pedagogics. The study was based on four stages which were as follows: a baseline study, model design, and description, expert evaluation, and analyses. The baseline study aimed at analysing the secondary education system in the Republic of Poland, and a teacher training system of inclusive education. The model was evaluated by experts using the questionnaire. The reliability score was 0.93 which was appropriate for this field of study. The SPSS Software (version 20) was used to analyse the data. The multiple-choice questions that were based on a five-point Likert scale were analysed using means and standard deviations. The data drawn from the open-ended questions were analysed using frequency distributions. Mann-Whitney U test calculator was employed to compare attitude score differences between the respondents' categories. A Chisquare test was used for the computation of the data between the groups of respondents. P-value of $\mathrm{p}<0.05$ was considered sufficient. The proposed model could be considered a benchmark for the professional training and consists of four blocks: value and objective, theory and best practices-related, content-based and procedural, productive. The designed model requires a rethinking and adaptation to the conditions of the system of higher education in Ukraine. Further research is needed in testing its effectiveness.
\end{abstract}

Keywords: inclusion; inclusive education; model; vocational training; primary school teacher; Republic of Poland 


\section{Introduction}

The guarantees of the right of every child to quality and affordable education are enshrined in a number of international documents (UNESCO, 1994, 2000; 2003; 2009; etc).

However, according to UNESCO (2009), in today's conditions, there are still many children not covered by school education, one-third of whom are children with disabilities. Other vulnerable groups include children belonging to ethnic indigenous minorities, rural population, linguistic minorities, nomads and those affected by HIV/AIDS. The theoretical foundations and practice of the implementation of inclusive education became especially topical for the solution to this problem. In a broad sense, this term is understood as an educational reform to support and promote diversity among all categories of pupils (Kugelmass, 2004). In the narrow sense, inclusive education is interpreted as a process of addressing and responding to the diverse needs of all children, youth and adults through their participation in learning, cultural activities, and community life. The purpose of inclusive education is to eliminate the exclusion of pupils from the educational process due to negative attitudes to and inadequate perception of racial, ethnic, economic, social, linguistic, religious and gender diversity (UNESCO, 2003).

At the same time, the documents mentioned above focus on the training, activities, and role of the teacher in the process of inclusive education. The Salamanca Statement and Framework for Action on Special Needs Education (UNESCO, 1994) emphasised the importance of training teachers, both pre-professional and part-time, to ensure the education of people with special educational needs in inclusive schools. The Dakar Framework for Action, Education for All: Meeting our Collective Commitments (UNESCO, 2000) emphasises the need to improve the status, morale, and professionalism of teachers in the inclusive education system.

\subsection{Literature review}

The literature review found that the reform of higher pedagogical education is necessary. As Florian, Young and Rouse (2010) rightly pointed out, it is high time that it adhered to the principle of equality in education. In today's conditions, it is necessary to build a model that prepares a teacher for work in the system of inclusive education. The need for its development is due to several contradictions that modern scholars are paying attention to, namely between:

- Declaring the ideas of inclusion and their practical implementation, the obstacles in the educational institutions such as a large number of pupils in the classroom, the teacher workload is excessive, the inability to pay attention to all pupils, lack of support from the part of the administration, etc. (Materechera, 2018; Schlessinger, 2018; Stepaniuk, 2018; McKay, 2016; Ineland, 2015).

- The orientation of education towards the development of the potential of all categories of pupils, the need for differentiated learning, innovative methods, for example, polysensor, and the orientation of most curricula towards a "traditional" pupil (Mugambi, 2017; Krason \& Jaszczyszyn, 2006); 
- The desire of teachers to realise the values of inclusive education and inadequate vocational and pedagogical training, in particular, to create a supportive learning environment for pupils with different educational needs (Materechera, 2018; Mugambi, 2017; McKay, 2016; Black-Hawkins \& Amrhein, 2014).

In this regard, it is expedient to study Poland's advances in training for work; in the system of education of the Republic of Poland, the task of teachers and educational institutions, in general, is to meet the needs of pupils related to learning difficulties, personal interests, and abilities.

As it is known, primary education is the foundation of education, therefore, the object of the research is the process of training of primary school teachers in the Republic of Poland, and the purpose of the study was to develop a model of vocational training of primary school teachers for work in the system of inclusive education by applying extrapolation of Poland's advances in training for work and to identify how it was evaluated by the experts in Pedagogics.

\section{Methods}

The research relies on the methods which are as follows: the logic and systemic method (see the description in the baseline study section) that enabled to determine the main provisions of the education system of the Republic of Poland, in particular the system of inclusive education, as well as to study the peculiarities of the formation of human resources based on the study of the regulatory documents and scientific works of scholars; the method of pedagogical modelling made it possible to develop a model of vocational training of primary school teachers for work in the system of inclusive education by applying extrapolation of Poland's advances in training for work; the methods of systematisation and synthesis of the processed materials contributed to concluding, comprehension of results and perspectives of their further application. The expert evaluation - a qualitative tool - was used to assess the usability of the model of training a primary school teacher for work in the system of inclusive education. The study was based on four stages which were as follows: a baseline study, model design, and description, expert evaluation, and analyses (see Figure 1). The aim of the first-mentioned was to study best practices of inclusive secondary education in Poland. The second one was intended to design and describe such a comprehensive pedagogical model for training primary school teachers for work in an inclusive education system which might make a framework for the university curriculum. The purpose of the expert evaluation was to raise the credibility of the model. The analytical stage was dedicated to data processing, data interpretation, and concluding.

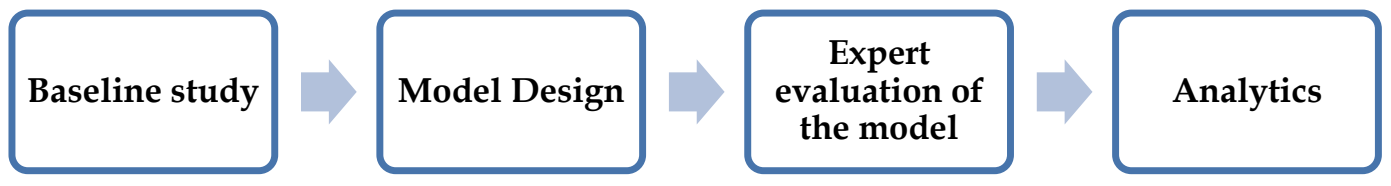

Figure 1: Visualised research flow 


\subsection{Baseline study: Best Practices of Secondary School Inclusive Education in Poland}

At this stage of the study, it was found that a consistent model of education was introduced in the Republic of Poland, which is regulated by the Law on the Right to Education of 2016 (Planipolic, 2017). This model applies to every pupil at all stages of education and involves the implementation of the following pedagogical conditions:

- In the system of preschool education an early observation and assessment of the child's readiness for school is conducted;

- Primary school identifies specific learning difficulties, skills and abilities of pupils and creates a system of individual support;

- In the secondary school, pupils are prepared to make responsible decisions about their further learning and professional paths through providing access to information, advice, and guidance.

The study of regulatory legal documents on the modern educational system in the Republic of Poland (Planipolic, 2017) makes it possible to conclude that the main principle of education is a creation of didactic situations which are supposed to enhance the inclusion of pupils with special educational needs, their development, the expansion of contacts with coevals and participation in the life of school community.

It is important to note that the educational reform in Poland is carried out from the beginning of 2017. Its main objective is that general secondary education should be the foundation for further personal development of all categories of pupils and their competitiveness in the modern labour market. The key elements in reforming primary education are the reformation of 6-year primary schools into 8-year ones. Primary education is divided into three mandatory stages: a preparatory stage lasting a year to get basic knowledge and skills by children for admission to their first grade, and is implemented in preparatory groups based on kindergartens or in schools; first (basic) - I-III grades for children aged 6-7 up to 10 years, where one teacher is teaching (except for foreign language, music, and physical training); the second - IV-VII grades for children aged 9-10 to 13-14, where teachers are teaching different subjects (European Commission, 2019).

Of particular interest to our study is the first stage of elementary education (primary school) and training of a teacher for work in the conditions of inclusive education. It has been found that pupils with special educational needs can attend different types of institutions of general secondary education:

1) Comprehensive schools providing inclusive education;

2) Integration classes based on comprehensive schools;

3) Special schools for the blind and visually impaired, deaf children and those with hearing impairments, children with mental or physical disabilities, sick children (these schools are located in hospitals); 
4) Centers for children and youth with social disorientation.

Parents are responsible for choosing a school for a child, including a child with a disability (European Commission, 2019).

Referring to the scientific researches of the Polish scholars Kulesza and Gosk (2015), Ober, Twardowski, and Pierson (2015) and others, we investigate the peculiarities of the development of staff capacity for work in the system of inclusive education. In the Republic of Poland, systemic teacher training for working with children and adolescents with disabilities began in the 1920s. The initiator of its introduction was the educator and psychologist Maria Grzegorzewska, and in 1922, such outstanding educators as Józef Joteyko, Janusz Korczak, Janina Doroszewska, Khalina Jankowska, and Natalie Khan-Ilkevich taught the students of the State Institute of Special Education which was created by her initiative. Gradually, in 1970 the institute received the status of a professional college, which made it possible to implement Master's Programs from 1973. In 1976, the college was transformed into the Higher School of Special Education named after Maria Grzegorzewska (Wyższa Szkoła Pedagogiki Specjalnej im Marii Grzegorzewskiej). In 1989, this educational institution received the right to award Doctorate in Pedagogy. The next step was the transformation of the higher school into a university (2000) - the Academy of Special Pedagogy named after Maria Grzegorzewska (Akademia Pedagogiki Specjalnej im. Marii Grzegorzewskiej). At the present stage, the Academy is the leading institution of higher education in the Republic of Poland, which provides training for work in the inclusive education system.

An analysis of the Academy's website indicates that there are many educational programs related to the education of pupils with special needs, such as Therapeutic Education, Pedagogical Therapy, Integration, and Inclusive Therapy, Pedagogy of Re-socialization, etc. for the training of teachers and assistant teachers who work with pupils with intellectual, visual, auditory, speech, physical impairment, emotional and behavioural disorders at different stages of education. Students are trained to work both in comprehensive schools and in special education centres.

Future specialists for social prevention, family support, culture and education services; adult continuous education systems; employment counselling services, etc. are trained using social pedagogy programs. In our opinion, a program on psychology and pedagogy of creativity, which is designed to train teachers for non-standard types of educational activities with children is interesting. The artistic education program in the field of fine arts is of particular interest, which also refers to the training of teachers for work in the system of inclusive education since art performs not only aesthetic but also therapeutic and rehabilitation function (The Maria Grzegorzewska University, 2017).

Teacher training for primary education, including work in the inclusive education system, is implemented on the basis of the Faculty of Education and Psychology of the Maria Curie-Skłodowska University (Uniwersytet Marii CurieSkłodowskiej) in Lublin. The Faculty participates in the European Primary Teacher Education (EPTE) International Cooperation Project. In addition to Maria 
Curie-Skłodowska University, the project participants are students and lecturers from the universities of Austria, the Netherlands, Portugal, Slovakia, and Slovenia. With the support of the Erasmus Foundation, Polish students as members of an international student group have the opportunity to study during the semester at one of the partner universities that implement EPTE. The curriculum consists of six subject modules that are taught in English: Pedagogy and Didactics, Multilingual and Intercultural Education, Society, Culture and Education, Mathematics, Natural and Social Sciences and Art (UMCS, n.d.b).

There is also an educational program in Education and Therapy for both Polish and foreign students at the university. The objective of the program is to acquire the skills necessary to help people with disabilities to reveal their potential. The acquired competencies allow graduates to work in the fields of rehabilitation, education, professional development, employment, leisure and to cooperate effectively with people with disabilities, their families, social workers, educators, psychologists, physiotherapists, and other specialists to include people with special needs in social life. Studying under this program, which combines the study of general problems of psychology and special education with studies on inclusion, early intervention, and rehabilitation makes it possible to acquire the necessary practical skills for conducting therapeutic and rehabilitation activities with children, adolescents and adults with intellectual disabilities, limited mobility, visual and hearing impairment, chronic diseases and mental disorders (UMCS, n.d.a).

\subsection{Description of the model}

For developing a pedagogical model for training primary school teachers for work in an inclusive education system, the work of Smantser and Ignatovitch (2015) is valuable to our study, who examine the teacher's training model for work in the inclusive educational environment and understand it as a set of interrelated components: regulatory and legal, motivational and objective, content and informational, operational and technological, organizational and planning, emotional and volitional, evaluative and reflexive, productive and corrective.

We consider that the model of training of primary school teachers for work in the system of inclusive education is an algorithm for planning and implementing the abovementioned process and covers four blocks, which reflect the interaction of structural and functional components of vocational training (Figure 2). We further present an overview of the blocks of the above model in detail. 


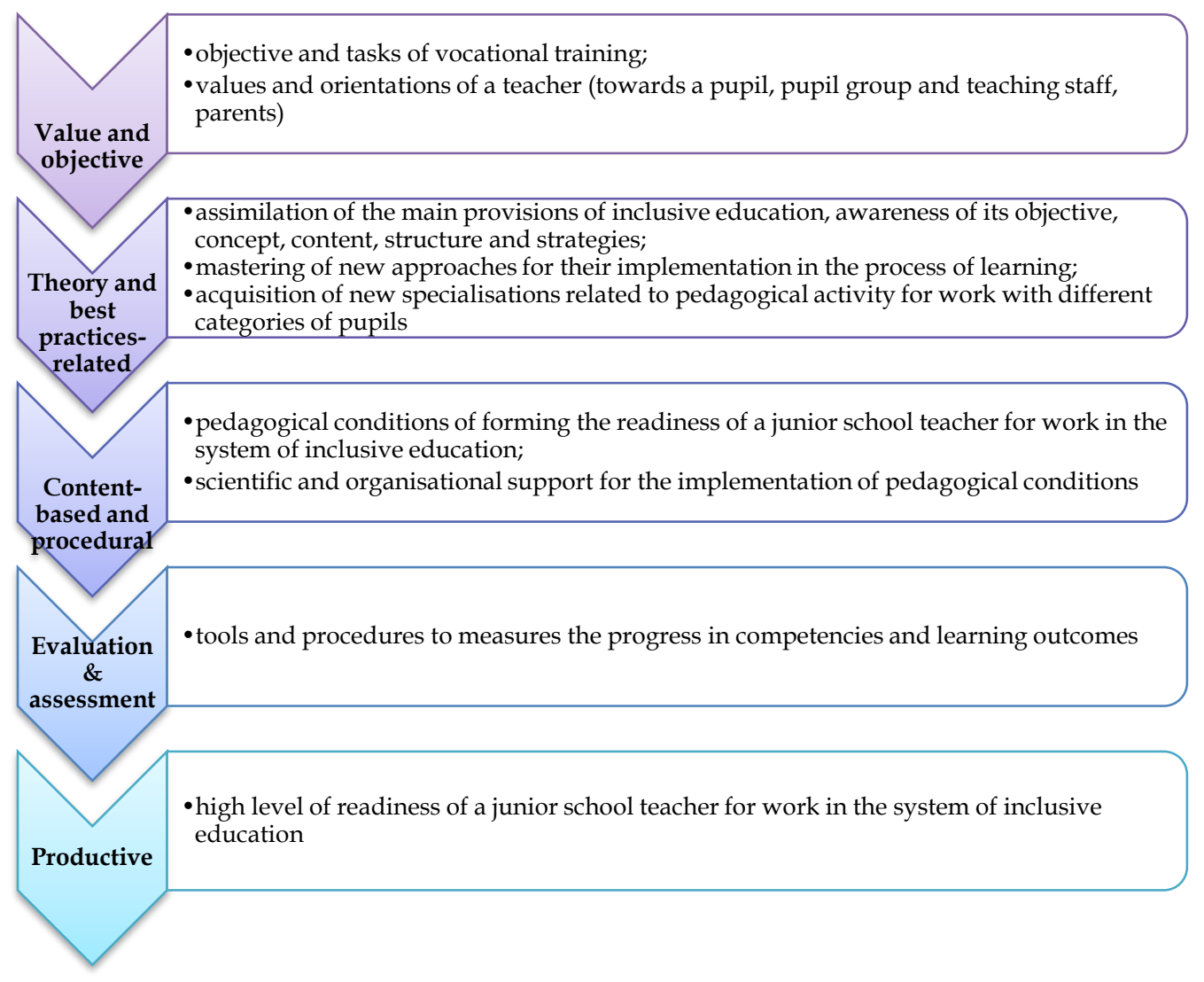

Figure 2: The model of training a primary school teacher for work in the system of inclusive education

The block of values and objectives relies on the purpose and objectives of vocational training, as well as the value orientations of a teacher. The purpose of vocational training is to form the readiness of the primary school teacher for work in inclusive education, and the task is to direct the teacher to the implementation of inclusive education, to urge its motives and values; to ensure the acquisition of knowledge about the essence of inclusion and skills for its implementation in the process of training of primary school pupils; facilitate teacher's acquisition of practical experience in the implementation of inclusive education.

The formation of a primary school teacher's values and orientations is particularly significant in the process of vocational training. Polish explorers Cyran, Kudláček, Block, Malinowska-Lipień and Zyznawska (2017) identified positive and negative teacher's sets when working with the inclusive class.

The following are among the positive ones: the inclusion of pupils with disabilities will encourage other pupils to learn about people with disabilities, help them learn how to interact with them, help them, show tolerance, and, in turn, pupils with disabilities will experience a dynamic personal development: self-esteem will be enhanced, a sense of group membership will be formed.

The negative sets are the following: inclusion of pupils with disabilities will impede the planning and preparation of lessons, reduce the quality of teaching, 
retard the educational progress of other pupils, and in turn, pupils with disabilities will feel discriminated against (Cyran et al., 2017). In our view, teachers' awareness of both positive and negative attitudes in the process of working with different categories of pupils will help him learn (HOW) to regulate his emotional state, maintain a balance between the internal state and external circumstances.

Polish scholar Kijak (2017a, 2017b) identifies teacher's value orientations in the process of work in the system of inclusive education and divides them into the following groups:

1) value orientations towards a pupil: the development of pupil as a personality ability to gain knowledge and skills, support of pupils' optimism, ability to apply for help and provide it;

2) value orientations towards a pupils' group: the development of the class as a community, in which the needs of others are noticed, the respect for diversity, the feelings of collectivism are manifested, mutual assistance is rendered;

3) value orientations towards the educational staff of the educational institution: responsibility, readiness to work in a team (ability to accept constructive criticism, to help others, to give advice, to show mutual trust);

4) value orientations towards parents: readiness for interaction (openness to propositions, communicativeness, tolerance, and faith in their children's success, honesty).

We consider the above classification as meaningful and expedient since it reflects the interaction of all subjects of inclusive education - children, parents, and teachers.

The theory and best practices-related block provides for the assimilation of the main provisions of inclusive education by a primary school teacher. The opinion of the Polish researcher Szpak (2017) that the introduction of inclusive education requires significant changes, firstly, in thinking, that is, an awareness of the objective of education, which consists in transforming the educational system which responds to the diverse needs of students and their provision, as well as revealing of individual potential of every pupil. Secondly, the changes in the content, concept, structure, and strategies of education are required to be made.

Other Polish scholars express a similar view, in particular, Przybylska and Wajsprych (2018), emphasise that educational practice must be adapted to the requirements and expectations of the social environment. Summarizing the thoughts of scholars, we note that the professional training of primary school teachers for work in the system of inclusive education requires the mastering of new approaches for their implementation in the educational process. For example, to develop religious tolerance and respect for refugees and their cultures, the scholars advise applying a hermeneutic approach in the process of teacher training, which consists in the assimilation of a new model of inclusive education 
- a supra-confessional, pluralistic, open to becoming acquainted with other systems of religions and beliefs. Scientists Kulesza and Gosk (2015) consider it necessary for a teacher to incorporate the dialogic approach, which is realized through the following stages: acquaintance with a pupil with special needs, understanding his needs and interaction with him.

For effective theoretical and methodological training, a future teacher should acquire new specializations related to the pedagogical activity. Scholars Kulesza and Gosk (2015) give examples of such specialisations as speech therapy, deafand-dumb pedagogy, blind pedagogy, and others, that should be mastered by a future teacher for work with different categories of pupils.

The content and procedural block reflect the pedagogical conditions for the formation of a primary school teacher's readiness for work in the system of inclusive education, as well as scientific and organizational support for their implementation. While distinguishing and justifying the first two pedagogical conditions, we rely on the studies of Starczewska, Hodkinson and Adams (2012). The authors found that the level of professional development of teachers in the Republic of Poland and the personal attitude to inclusion (BOTH) influence the effectiveness of its implementation. The researchers point out that the concept of inclusion is not fully implemented in the educational process, while integrative learning dominates. Given the above, the first pedagogical condition is defined as the formation of the system of motives and values of a future primary school teacher, aimed at the implementation of inclusive education. The second pedagogical condition is the teacher's acquisition of a system of knowledge about the essence of inclusion and the peculiarities of its introduction into the process of teaching primary school pupils.

In the justification of the third and fourth pedagogical conditions, we rely on the Decree of the Minister of Science and Higher Education of the Republic of Poland dated January 17, 2012, regarding the standards of teacher training (ISAP, 2012). The document focuses on the importance of practical teacher training for working with pupils, including pupils with special educational needs. For this, the teacher needs the ability to develop and adjust curricula to the needs and abilities of pupils; to individualize tasks, to choose methods and content of training; to conduct individual educational activities for pupils with special educational needs. When summarising the thoughts of the predecessors, Przybyszewska (2014) emphasises the role of a teacher in creating the conditions for the development of each pupil, the selection of material and methods of work for pupils, the formation of tolerance in them, the motivation for learning and creation of opportunities for cooperative interaction between children. Therefore, the third pedagogical condition is determined to be the development of the teacher's skills necessary for the implementation of inclusive education, and the fourth is the acquisition by a teacher of practical experience in the implementation of inclusive education.

While determining the scientific and organizational support for the implementation of the pedagogical conditions for the formation of the readiness of a primary school teacher for work in the system of inclusive education, we use the work of Kulesza and Gosk (2015), who propose the following measures: 
independent choice of specializations and subjects; study of domestic and foreign sources, regulatory and legal documentation on inclusive education; own scientific researches; participation in pedagogical workshops and internships. The scholars suggest the administration and faculty to increase the number of practical classes on the methods of pupil assessment to be attended by students, methods of conducting seminars to be attended by parents; monitor the labour market and enhance the work of the Graduates Employment Unit.

The evaluation block addresses tools and procedures to measures the progress in students' competencies and learning outcomes so that the necessary adjustments could be made to the model.

The productive block reflects the high level of readiness of a primary school teacher for work in the system of inclusive education. Kijak (2017a) sees the results of the teacher's readiness in the ability to diagnose the needs and abilities of pupils and consider diagnosing as a continuous process; to develop individual educational programs, adapt them to the needs of individual pupils; to introduce new forms and methods of work; to evaluate pupils applying an individual approach.

\subsection{Sample of the experts participating in the evaluation}

Nineteen experts were randomly involved to participate in the evaluation of the model of primary school teachers training for work in the system of inclusive education based on best practices adopted to form the education system in the Republic of Poland. The experiment involved 254 teachers who attended the inservice training course and 27 lecturers at the Chernivtsi Institute of PostGraduate Pedagogical Education (CIPGPE) and the Sumy State Pedagogical University, named after Anton Makarenko (SSPU) (see Table 1). The working experience of $47 \%$ of sampled people was more than 10 years, the working experience of $33 \%$ of volunteers was up to 10 years; the teaching experience of the rest of experts $(20 \%)$ was longer than 20 years. $28 \%$ of them were qualified as "teacher-methodologists". $83 \%$ of lecturers were the holders of a scientific degree (Dr or Ph.D.) in Pedagogics.

Table 1: Demographics of experts participating in the evaluation

\begin{tabular}{|l|c|c|c|c|}
\hline & & $\begin{array}{c}\text { CIPGPE, Mean } \pm \\
\text { SD, } \%\end{array}$ & $\begin{array}{c}\text { SSPU, Mean } \pm \\
\text { SD, } \%\end{array}$ & p-value \\
\hline \multirow{2}{*}{ Gender } & $\mathrm{M}$ & 26.2 & 55.9 & \multirow{2}{*}{$p<0.001$} \\
\cline { 2 - 4 } & $\mathrm{F}$ & 73.8 & 44.1 & \multirow{2}{*}{0.108} \\
\hline Teachers & & 82.9 & 93.1 & \multirow{2}{*}{0.219} \\
\hline $\begin{array}{l}\text { University } \\
\text { lecturers }\end{array}$ & & 17.1 & 9.9 & \\
\hline $\begin{array}{l}\text { Working } \\
\text { experience } \\
\text { (years) }\end{array}$ & 10 to 20 years & 13 & 20 & \multicolumn{2}{|c}{} \\
\cline { 2 - 5 } & $<20$ years & 12 & 8 & \multicolumn{2}{|c}{} \\
\hline
\end{tabular}




\subsection{Instruments}

The expert evaluation questionnaire comprised of 38 questions. There were multiple-choice and open-ended questions. They covered respondents' demographics, working in the field, beliefs and attitudes, instructional intentions, theory, and methodology. Two experienced experts were involved in piloting the validation and review of the questionnaire. After the amendments have been made, the internal reliability of the questionnaire was measured with Cronbach's Alpha Formula. The reliability score was 0.93 which was appropriate for this field of study (Bolarinwa, 2015; Solans-Domènech, Pons, Adam, Grau \& Aymerich, 2019). The SPSS Software (version 20) was used to analyse the data. The multiple-choice questions that were based on a five-point Likert scale were analysed using means and standard deviations. The data drawn from the open-ended questions were analysed using frequency distributions. Social Science Statistics (n.d.) was employed to compare attitude score differences between the respondents' categories. A Chi-square test was used for the computation of the data between the groups of respondents. P-value of $p<0.05$ was considered sufficient.

\section{Results}

The outcome of this study was the model of vocational training of primary school teachers for work in the system of inclusive education that was based on best practices of training for working in this instructional environment in Poland (see Fig 2). The model consisted of five blocks. Those blocks were values and objectives, theoretical and methodological, content and procedural, evaluation and productive. The model might be used as a continuous cycle, every time being adjusted to meet stricter regulatory or educational requirements. The model is flexible and easily integrated into teacher vocational training. The effectiveness of the model can be monitored and measured by the progression of students in target competencies and learning outcomes.

The results of the evaluation of the model by experts in Pedagogics are presented in Table 2.

Table 2: Results of the evaluation of the model by experts

\begin{tabular}{|c|c|c|c|c|c|c|c|c|}
\hline Factors & Respondents & Yes & TSE & No & Total & $\chi^{2}$ & $d f$ & $p$ \\
\hline \multirow{2}{*}{$\begin{array}{l}\text { Theoretical and } \\
\text { methodological } \\
\text { value }\end{array}$} & Teachers & 159 & 72 & 23 & 254 & 44.36 & 3 & \multirow[b]{2}{*}{$<0.05$} \\
\hline & Lecturers & 23 & 4 & 0 & 27 & 21.87 & 1 & \\
\hline \multirow{2}{*}{$\begin{array}{l}\text { Procedural } \\
\text { appropriateness }\end{array}$} & Teachers & 144 & 67 & 42 & 253 & 49.73 & 2 & \multirow{2}{*}{$<0.05$} \\
\hline & Lecturers & 22 & 4 & 1 & 27 & 19.91 & 1 & \\
\hline \multirow{2}{*}{$\begin{array}{l}\text { Inclusive } \\
\text { environment } \\
\text { relevance }\end{array}$} & Teachers & 139 & 68 & 47 & 254 & 44.07 & 2 & \multirow[b]{2}{*}{$<0.05$} \\
\hline & Lecturers & 19 & 7 & 1 & 27 & 8.34 & 1 & \\
\hline \multirow{2}{*}{$\begin{array}{l}\text { Willingness to } \\
\text { use it }\end{array}$} & Teachers & 214 & 25 & 15 & 254 & 43.39 & 7 & \multirow{2}{*}{$<0.05$} \\
\hline & Lecturers & 25 & 1 & 1 & 27 & 21.22 & 1 & \\
\hline
\end{tabular}

The results of the evaluation of the model by experts were suggestive in terms of identifying the advantages and disadvantages of the model. As can be seen, about 
a quarter of experts were hesitant about its theoretical and methodological value, inclusive environment relevance, and procedural appropriateness. However, the majority expressed willingness to use it which indicated that the experts could either use it as it was or modify it to meet their purpose.

\section{Discussion}

This study goes in line with our literature review findings and contributes to the study of the theory and methods vocational training of primary school teachers for work in the system of inclusive education. First, the study broadened previous studies dedicated realising the values of inclusive education in teacher training (Ozel, Ganesan, Daud, Darusalam \& Ali, 2018; You, Kim \& Shin, 2019). It was found that more experienced instructors tended to acknowledge the influence of inclusive education on socialisation, self-efficacy, cognitive development of children with disabilities. We share the point of view of the Polish scholar Szpak (2017), who emphasises that the effective realisation of the goals of inclusive education should be based on the integrated training of teachers, obtaining the necessary qualifications and competencies. However, as the researcher rightly observes, teachers are not the only link in the development of an inclusive school but are only part of a wider system. In our view, the presented model of training primary school teachers for work in the system of inclusive education by applying extrapolation of Poland's advances in training for work will promote the development of a personal pedagogical trajectory by the teacher, the formation of an individual style of the pedagogical activity, and the creation of an inclusive educational environment.

Together with the introduction of this model, the experts articulated two challenges that the teachers are supposed to meet. Those were as follows: first, adjusting to a new role (Durlak \& DuPre, 2008), second, establishing enhanced colleague cooperation (Fullan, 2014).

The results of the study suggest that the developed model with the criterion and diagnostic block to determine and measure the criteria with the indicators of the levels of readiness of a primary school teacher for work in the system of inclusive education, as well as the reflexive and corrective - for teacher's self-assessment of the level of readiness and self-correction. It is, however, necessary to take into account the domestic experience of the introduction of inclusive education and the development of its staffing. In this regard, a comparative analysis of the Polish and Ukrainian experience in this field is advisable.

\section{Conclusions}

Based on the study of legal documents and scientific works of Polish scholars, a pedagogical model of training primary school teachers for work in the system of inclusive education was developed. The proposed model is a benchmark for the process of professional training and consists of four blocks: value and objective (objective and tasks of vocational training, teacher values and orientations), theory and best practices-related (main provisions of inclusive education, new approaches to the learning process, acquisition of new specializations), contentbased and procedural (pedagogical conditions of forming the readiness of primary school teachers for work in the system of inclusive education, as well as 
scientific and organizational support for the implementation of pedagogical conditions), evaluation and assessment, and productive (high level of readiness of a primary school teacher for work in the system of inclusive education). The developed model requires a rethinking and adaptation to the conditions of the system of higher education in Ukraine. We consider the practical implementation of the model in the process of pedagogical experiment and verification of its effectiveness as prospects for further scientific research.

\section{References}

Black-Hawkins, K., \& Amrhein, B. (2014). Valuing student teachers' perspectives: researching inclusively in inclusive education? International Journal of Research $\mathcal{E}$ Method in Education, 37(4), 357-375. https:// doi.org/10.1080/1743727x.2014.886684

Bolarinwa, O. A. (2015). Principles and methods of validity and reliability testing of questionnaires used in social and health science researches. Nigerian Postgraduate Medical Journal, 22(4), 195-201. https://doi.org10.4103/1117-1936.173959

Cyran, M., Kudláček, M., Block, M., Malinowska-Lipień, I., \& Zyznawska, J. (2017). Attitudes of teachers towards the inclusion of students with disabilities in physical education: Validity of the ATIPDPE-R instrument in Polish cultural context. Acta Gymnica, 47(4), 171-179. https://doi.org/10.5507/ag.2017.020

Durlak, J. A., \& DuPre, E. P. (2008). Implementation matters: A review of research on the influence of implementation on program outcomes and the factors affecting implementation. American Journal of Community Psychology, 41(3-4), 327-350. https:// doi.org/10.1007/s10464-008-9165-0

European Commission. (2019). Poland Overview. Retrieved from https://eacea.ec.europa.eu/national-policies/eurydice/content/poland_en

Florian, L., Young, K., \& Rouse, M. (2010). Preparing teachers for inclusive and diverse educational environments: studying curricular reform in an initial teacher education course. International Journal of Inclusive Education, 14(7), 709-722. https://doi.org/10.1080/13603111003778536

Fullan, M. (2014). Teacher development and educational change. London, UK: Routledge Falmer.

Ineland, J. (2015). Logics and ambivalence - professional dilemmas during the implementation of an inclusive education practice. Education Inquiry, 6(1). https://doi.org/10.3402/edui.v6.26157

ISAP. (2012). Rozporzadzenie Ministra Nauki i Szkolnictwa Wyzszego z dnia 17 stycznia 2012 r. $w$ sprawie standardów ksztalcenia przygotowujacego do wykonywania zawodu nauczyciela [Ordinance minister of science and higher education of 17 January 2012 on the standards of education preparing for the teaching profession]. Retrieved from http:// prawo.sejm.gov.pl/isap.nsf/DocDetails.xsp?id=WDU20120000131

Kijak, R. (2017a). Learning - teaching approach: Polish case inclusion. In A. Galkienè (Ed.), Socio-Educational Frames Inclusive School Cases in Four European Countries (pp. 431439). Vilnius, Lithuania: Lithuanian University of Educational Sciences.

Kijak, R. (2017b). Professional interaction network of the teacher: Polish case inclusion. In A. Galkienè (Ed.), Socio-Educational Frames Inclusive School Cases in Four European Countries (pp. 413-419). Vilnius, Lithuania: Lithuanian University of Educational Sciences. 
Krason, K., \& Jaszczyszyn, E. (2006). Early education and inclusion in Poland. Early Child Development and Care, 176(6), 621-630. https:/ / doi.org/10.1080/03004430500147433

Kugelmass, J. (2004). What is a Culture of Inclusion? Retrieved from https://www.eenet.org.uk/enabling-education-review/enabling-education8/newsletter-8/8-14/

Kulesza, E., \& Gosk, U. (2015). Training teachers at the Maria Grzegorzewska Academy of Special Education in Warsaw. Pedagogical science and education, 10(1), 83-92.

Materechera, E. K. (2018). Inclusive education: why it poses a dilemma to some teachers. International Journal of Inclusive Education, 1-16. https:// doi.org/10.1080/13603116.2018.1492640

McKay, L. (2016). Beginning teachers and inclusive education: frustrations, dilemmas, and growth. International Journal of Inclusive Education, 20(4), 383-396. https:// doi.org/10.1080/13603116.2015.1081635

Mugambi, M. M. (2017). Approaches to inclusive education and implications for curriculum theory and practice. International Journal of Humanities Social Sciences and Education, 10(4), 92-106. https://doi.org/10.20431/2349-0381.0409013

Ober, K. M., Twardowski, A., \& Pierson, M. R. (2015). Inclusive education in Poland: Policies, practices, and perspectives. Including Learners with Low-Incidence Disabilities, 5, 315-339. https:/ / doi.org/10.1108/s1479-363620140000005024

Ozel, E., Ganesan, M. Z., Daud, A. K. M., Darusalam, G. B., \& Ali, N. A. (2018). Critical issue teacher training into inclusive education. Journal of Computational and Theoretical Nanoscience, 24(7), 5139-5142. https:/ / doi.org/10.1166/asl.2018.11288

Planipolic. (2017). Ustawa z dnia 14 grudnia 2016 r. Prawo oświatowe [Law of December 14, 2016 - Educational Law]. Retrieved from https:/ / planipolis.iiep.unesco.org/en/2017/ustawa-z-dnia-14-grudnia-2016-rprawo-o\% C5\%9Bwiatowe-6665

Przybylska, E., \& Wajsprych, D. (2018). Social worlds and religious education in Poland: towards the elimination of disharmony. British Journal of Religious Education, 42(2), 202-213. https://doi.org/10.1080/01416200.2018.1556601

Przybyszewska, D. (2014). Parents of children studying in integrated classes - their motives and expectations. Interdisciplinary Contexts of Special Pedagogy, 6, 49-68. https://doi.org/10.14746/ikps.2014.6.03

Schlessinger, S. L. (2018). Reclaiming teacher intellectualism through and for inclusive education. International Journal of Inclusive Education, 22(3), 268-284. https:/ / doi.org/10.1080/13603116.2017.1362598

Smantser, A., \& Ignatovitch, E. (2015). Future teacher training for work in inclusive educational environment: experimental study results. Procedia - Social and Behavioral Sciences, 214, 422-429. https:/ / doi.org/10.1016/j.sbspro.2015.11.699

Social Science Statistics. (n.d.). Mann-Whitney $U$ test calculator. Retrieved from https://www.socscistatistics.com/tests/mannwhitney/

Solans-Domènech, M., Pons, J. M. V., Adam, P., Grau, J., \& Aymerich, M. (2019). Development and validation of a questionnaire to measure research impact. Research Evaluation, 28(3), 253-262. https:/ / doi.org/10.1093/reseval/rvz007

Starczewska, A., Hodkinson, A., \& Adams, G. (2012). Conception of inclusion and inclusive education: A critical examination of the perspectives and practice of teachers in Poland. Journal of Research in Special Educational Needs, 12, 162-169. https://doi.org/10.1111/j.1471-3802.2011.01209.x

Stepaniuk, I. (2018). Inclusive education in Eastern European countries: a current state and future directions. International Journal of Inclusive Education, 23(3), 328-352. https://doi.org/10.1080/13603116.2018.1430180 
Szpak, A. (2017). Inclusive education for students with disabilities - the contemporary $\begin{array}{llll}\text { challenges. } & \text { Civilizations } & \text { Rapprochements, }\end{array}$ https://doi.org/10.21784/zc.2017.022

The Maria Grzegorzewska University. (2017). University. Retrieved from http://www.aps.edu.pl/University/

UMCS. (n.d.a). Education and Therapy (MA). Retrieved from https://www.umcs.pl/en/education-and-therapy-ma-,14662.htm\#page-1

UMCS. (n.d.b). Faculty of Education and Psychology. Retrieved from https:// www.umcs.pl/en/faculty-of-education-and-psychology,2658.htm

UNESCO. (1994) The Salamanca Statement and Framework for Action on Special Needs Education. Retrieved from https://www.right-to-education.org/sites/right-toeducation.org/files/resource-attachments/Salamanca_Statement_1994.pdf

UNESCO. (2000). The Dakar Framework for Action: Education for All: meeting our collective commitments. $\quad$ Retrieved from https://www.academia.edu/9877228/Education_for_All_Meeting_our_Collecti ve_Commitments_Including_six_regional_frameworks_for_action_The_Dakar_ Framework_for_Action_World_World_Education_Forum_Education_Forum

UNESCO. (2003). Overcoming Exclusion through Inclusive Approaches in Education. A challenge and a vision. Paris, France: UNESCO.

UNESCO. (2009). Policy Guidelines on inclusion in education. Paris, France: UNESCO.

You, S., Kim, E. K., \& Shin, K. (2019). Teachers' belief and efficacy toward inclusive education in early childhood settings in Korea. Sustainability, 11(5), 1489. https://doi.org/10.3390/su11051489 